\title{
Usefulness of bovine and porcine IVM/IVF models for reproductive toxicology
}

\author{
Regiane R Santos ${ }^{1,2^{*}}$, Eric J Schoevers ${ }^{3}$ and Bernard AJ Roelen ${ }^{3,4}$
}

\begin{abstract}
Women presenting fertility problems are often helped by Assisted Reproductive Techniques (ART), such as in vitro fertilization (IVF) programs. However, in many cases the etiology of the in/subfertility remains unknown even after treatment. Although several aspects should be considered when assisting a woman with problems to conceive, a survey on the patients' exposure to contaminants would help to understand the cause of the fertility problem, as well as to follow the patient properly during IVF. Daily exposure to toxic compounds, mainly environmental and dietary ones, may result in reproductive impairment. For instance, because affects oocyte developmental competence. Many of these compounds, natural or synthetic, are endocrine disruptors or endocrine active substances that may impair reproduction. To understand the risks and the mechanism of action of such chemicals in human cells, the use of proper in vitro models is essential. The present review proposes the bovine and porcine models to evaluate toxic compounds on oocyte maturation, fertilization and embryo production in vitro. Moreover, we discuss here the species-specific differences when mice, bovine and porcine are used as models for human.
\end{abstract}

Keywords: Female fertility, Toxicology, Bovine, Porcine, Model

\section{Background}

The adverse effects caused by various natural and synthetic chemicals include impairment of both the male and the female reproductive system. Many of these effects are related to temporary or permanent actions on the endocrine system. When the mechanisms of action of these chemicals are endocrine-mediated, they may induce non-heritable defects culminating with sub/infertility, growth retardation, endocrine disorders or even death of the organism/subpopulation or its descendants [1].

Subfertility of women at reproductive age is often caused by endocrine disorders, occasionally ( $10 \%$ of the cases) characterized by polycystic ovary syndrome (PCOS) $[2,3]$. Although there is strong evidence that PCOS is a genetic disease, diagnoses do not always indicate the cause of the sub/infertility neither the mode of action of the causative agent [4]. It has been shown that PCOS can be correlated with exposure to the endocrine disruptor bisphenol A (BPA) [5]. Also, women with PCOS when

\footnotetext{
* Correspondence: R.Rodriguesdossantos@pq.cnpq.br

'Institute for Risk Assessment Sciences, Faculty of Veterinary Medicine, Utrecht University, P.O Box 80152, 3508 TD Utrecht, The Netherlands 2Laboratory of Wild Animal Biology and Medicine, Federal University of Pará, Rua Augusto Corrêa, Campus Básico, CEP 66075-110 Belém, Pará, Brazil Full list of author information is available at the end of the article
}

exposed to nicotine have a higher chance to acquire other metabolic disorders [6]. Probably, many other endocrine active substances present in the environment, food, drugs or cosmetics will also cause subfertility. More than $25 \%$ of the subfertility cases are of unknown etiology and remain not diagnosed, and the affected couples attempt to achieve their parenthood experience through ART. However, knowledge on the source of subfertility, as well as the risks of oocyte defects during maturation will improve the success of IVF programs. Women exposed to a determined toxic agent may have a temporary negative effect on their oocyte quality, which may reflect on the health of the offspring.

Most information regarding reproductive toxicology has been obtained from case reports, clinical analyses and in vivo tests with mice and rats. The use of laboratory animals for such tests is under debate for many years [7], because in vivo reproductive toxicity tests require large numbers of animals. Indeed approximately $70 \%$ of all the animals used in toxicological studies are for assays involving reproductive toxicity [8]. Furthermore, rodents are not the most suitable model animals for human, especially when considering oocyte maturation and fertilization [9]. 
Although the in vivo assays should not as yet be eliminated, alternative assays including computational, integrative in vitro tests using embryonic stem cells and cell lines are novel approaches in reproductive toxicology $[10,11]$. Available screening tests for hormone-like active compounds do not identify endocrine disruptors nor assure that a chemical will have an endocrine activity [12]. Nevertheless, such tests are useful to suggest the potential effect of certain substances. Furthermore, if the tests are integrated and projected with a clear knowledge on the main targets of reproductive toxic compounds and their involved mechanisms, the use of a large number of laboratory animals can be avoided.

Due to their complexity, not always reproductive cells such as oocytes can be mimicked by somatic cells. Moreover, oocytes and their surrounding cumulus cells have to undergo a unique process known as maturation that for the oocyte includes meiosis. Indeed, during maturation, oocytes are susceptible to epigenetic alterations that may interfere with fertilization and early embryo development [13]. Accordingly, exposure to polycyclic aromatic hydrocarbons before ART affects oocyte quality, as observed in women with a lower rate of cell division after IVF [14]. By evaluating data from different laboratories, it has been suggested that maturation of bovine oocytes can be used as a reliable model to screen toxic agents for human oocytes [15-17]. Also, the use of the porcine model has been indicated to evaluate oocyte maturation as a model for human oocytes due to some similarities between these species [18-20]. Furthermore, both bovine and porcine models can reduce the large number of laboratory animals used for reproductive testing, since oocytes can be obtained from slaughterhouse ovaries which are leftover organs when animals enter the food production chain.

The REACH (Registration, Evaluation, and Authorization of Chemicals) legislation is a European program impacting manufacturers worldwide since 2007/2008. For instance, marketing in Europe of any chemical (pure form or in a formulation) is allowed solely if data on physical/chemical properties, toxicity and environmental effects are provided. As a result, there is an enormous increase in the number of experimental animals used to test the safety of many thousands of chemicals, existing and new ones [21]. However, the adopted EU directive from 2010 focus on the protection of animals used for scientific purposes and demands a decrease in the number of animals used in research, including toxicity (drug) testing [22]. Innovative approaches have been suggested by developing a battery of tests targeting aspects of the reproductive cycle, and by integrating the approaches based on the mechanisms in cells and tissues [21]. The possibility to use slaughterhouse material for in vitro tests related to gametes and early embryo development appears as an important option to diminish the number of in vivo tests.
The aim of the present review was to evaluate the usefulness of using bovine and porcine IVM/IVF as model for reprotoxicity studies. For this, we address reproductive toxins and toxicants and their main effects on female fertility focusing on in vitrooocyte maturation and fertilization. Moreover, the use of oocytes from cattle and pig provides insight on the possibilities to evaluate chemicals on the in vitro oocyte maturation, fertilization and early embryonic development (preimplantation stage) as a model for human.

\section{Methods}

The present review has been prepared based on a survey of data available in PubMed (1998 to June 2014), from which non-English manuscripts were excluded. The search terms were "oocyte", "in vitro maturation", "in vitro fertilization" and "toxicology", and two independent persons analyzed the data in the papers. Only studies indicating experimental procedures applying bovine and porcine cells as in vitro models were considered. Data from mice and human were also considered to compare with the bovine and porcine in vitro data. Most human data are from women submitted to ART procedures due to fertility problems. Review papers were used solely to support our introduction and discussion sections.

\section{Oocyte maturation, fertilization and embryo development: species differences}

Oogenesis is an extremely specialized process and, depending on the species, the formation of a mature oocyte from the initial oocyte enclosed in dormant primordial follicles is completed in several weeks, as in mice [23,24], or several months as in bovine, porcine and human [25-27]. Ovarian folliculogenesis is not detailed here, as it is well described in some recent reviews $[28,29]$. When an oocyte is fully grown, it is capable of resuming meiosis, but further follicle growth is necessary to deliver an oocyte that will mature properly and give rise to an embryo after fertilization. As means of toxicological research, this is a unique event because (i) apart from that it is completed in a relatively short period of time, 14 hours in mice to 44 hours in sows, cytoplasmic and nuclear maturation require dynamic interactions that will reflect the success of fertilization [30], (ii) species-specific differences have been described during chromatin configuration at germinal vesicle stages $[31,32]$, and (iii) the maturation process differs among mammalian species. For example, protein synthesis is required for germinal vesicle breakdown (GVBD) in cow [33], pig [34] and human [35], but not in mice [36]. More details on the differences between large mammals and laboratory animals are available in a review from Bilodeau-Goeseels [37].

In general, after ovulation, the mature oocyte is able to be fertilized and will give rise to an embryo after a series 
of coordinated processes in both sperm and oocyte: spermatozoa binding to the zona pellucida, an acrosome reaction which gives the ability to the spermatozoa to penetrate the zona pellucida, binding of the spermatozoa to the plasma membrane leading to membrane depolarization and $\mathrm{Ca}^{2+}$ dependent events that include cortical granule exocytosis, cell cycle resumption with concomitant decreases in maturation promoting factor (MPF) and mitogen-activated protein (MAP) kinase activities, and recruitment of maternal mRNAs. After zygote formation, depending on the species, a defined number of cellular divisions take place under control of maternal mRNAs, where after embryo development will be taken over by mRNAs transcribed from the embryonic genome. Embryos with insufficient embryonic DNA transcription will cease development. Parallel to these cellular divisions, from the zygote towards the morula/blastocyst stage the embryonic genome will be demethylated and thereafter be remethylated shortly before implantation. This process of DNA methylation is indispensable for proper embryo development and protects the embryo from premature death in utero $[38,39]$.

Although the oocyte has conserved developmental pathways throughout evolution, phylogenetic analysis of proteins that are involved with fertilization or embryonic development revealed that human oocytes are more closely related in this respect to cow oocytes than mouse oocytes [40]. Figure 1 depicts the main similarities among murine, bovine and porcine model when compared to human. For example, oocyte diameter, the time to reach the 2-cell stage, blastocysts or hatching is similar between human, porcine and bovine, but is shorter in mice. Moreover, the time period of oocyte maturation and initial embryo development is very similar when human and bovine are compared. When the developmental stage of embryonic genome activation is observed, then human is more similar to pigs than to cattle or mice [41-43]. The morphological similarity between oocytes from women and mice is related to the cellular opacity. In these species, oocytes are translucent, while oocytes from cows are dark and from sows are very dark, due to the accumulation of lipid vesicles in the ooplasm [44]. Even though the concentration of fatty acids differ between the oocytes of the afore mentioned species, their composition is similar between these gametes $[45,46]$. Lipids stored in the oocyte will function as energy source during oocyte maturation but used in a less extent during embryo development [47]. The role of the large lipid content throughout porcine embryo development remains unknown, as lipid removal from cleavage stage embryos does not seem to affect their further development to the blastocyst stage [48]. Despite of difference in oxygen consumption between bovine, mouse and porcine embryos, at the morula stage, a sharp rise of metabolic activity is recorded in all three species [44]. Murine oocytes have low amounts of fatty acids and are therefore more glucose dependent for embryo development than bovine or porcine oocytes [49]. DNA methylation results from the activity of DNA methyltransferases (DNMTs) and these proteins show a greater degree of structural similarity between human and bovine than between human and mouse [50-53].

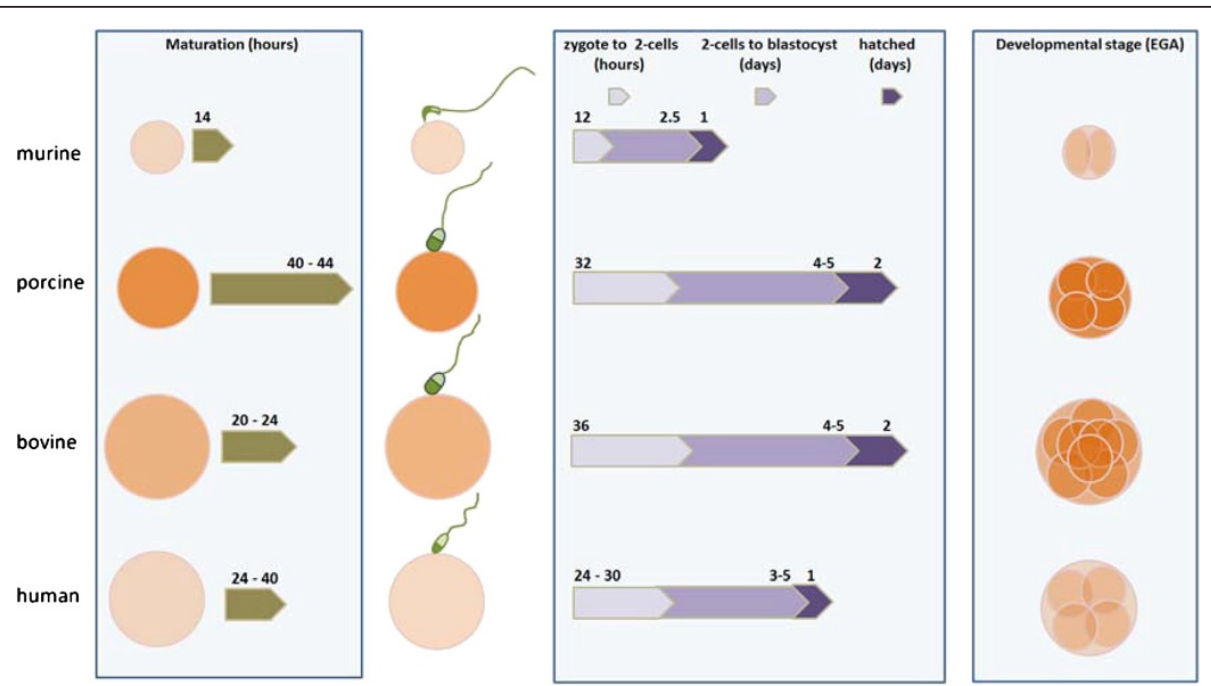

Figure 1 Main differences between murine, porcine, bovine and human oocyte size at maturation, time to maturation, early embryo development and embryonic genome activation (EGA). Color intensity of oocytes and embryos refers to lipid density. Mean size of oocytes at maturation are presented in proportion (mice $\sim 80 \mu \mathrm{m}$ ). Average time periods of maturation and embryo development after onset of fertilization are illustrated by block arrows: oocyte maturation in hours (green arrows), transition from zygote to two-cells stage in hours (light purple arrows), transition of two-cells to blastocyst stage in days (purple arrows), and time to hatched blastocysts in days (dark purple arrows). Data were collected from in vivo and in vitro studies [34,54-72]. 
Oocyte maturation, fertilization and subsequent embryo development involve multifaceted changes that are not easily mimicked by cell lines. Besides this, there are chronological and biochemical differences between laboratory and domestic mammals during the course of oocyte maturation and development of the embryo. Considering the feasibility to obtain ovaries from pigs and cows, the readily efficient protocols available from oocyte maturation to embryo production in vitro, as well as physiological and phylogenetic similarities, the use of these animal models in reproductive toxicology is encouraged [17,73,74]. Laboratory animals remain valuable research tools particularly humanized mice, i.e. those carrying functioning human genes, cell, tissues or organs [75]. However, oocyte maturation, fertilization and embryo development in mice cannot easily be genetically changed to be humanized; translational studies in these rodents will not always reflect the effects in human when female reproduction is evaluated.

\section{Exposure to toxic compounds in relation to reproductive failure}

People are constantly exposed to toxic compounds present in the environment, food, drugs, and for instance cosmetics or due to occupational exposure. Exposure to several chemicals may also vary between species. For example, pigs are environmentally exposed to polychlorinated biphenyl (PCB) and dioxins, which can accumulate in fatty tissues and meat [76]. Therefore, human contamination is also related to food consumption and, as accumulated in fat, risks of exposure to new-born babies during breast-feeding is evident [77]. Human antidepressants, on the other hand, have been described as causing reproductive disorders in mice [78], while no clear effects on human fertility could be detected $[79,80]$. However, such drugs can become important environmental reproductive toxicants in the aquatic environment [81]. Phthalates are environmental contaminants also used in the coating of oral medications, making the drug as a toxicant exposure source [82]. Another agent, acrylamide, is known as an occupational toxicant [17]. However, this compound can also be produced during food processing [83], including baby food and infant formulas [84], and can pass through the placenta thereby affecting fetal growth [85]. Moreover, as shown in bovine [17], acrylamide affects oocyte maturation. In the present review, we divided the toxic compounds in five main categories (environmental, food, drugs, cosmetics or occupational) for didactical reasons. For details on specific toxic compounds, Table 1 is given as reference.

\section{Environmental toxic compounds}

Although the use of some agricultural fertilizers, pesticides or animal parasitical solutions has been banned or diminished in many countries, the ability of these substances to persist in the environment (soil and water resources) presents a threat to human and animal health. This means that the negative effect of these compounds may be present longer in a population than in the environment. Moreover, for every toxic compound that has been banned or diminished, one or even more hazardous substances have come back due to adaptations in the production of new so-called less harmful metabolites. Therefore, the final threat may even increase instead of decrease or stabilize. For instance, atrazine is a 21st century herbicide which also acts as an endocrine disruptor [115] and its metabolites such as desethylatrazine [116] and cyanuric acid [117] might persist in the environment. In human, a survey quantifying biomarkers in maternal and umbilical cord serum to detect in utero exposure to pesticides showed that those agricultural contaminants affect offspring outcome and development [118]. Many reproductive dysfunctions are likely caused by environmental toxicants. To exclude this source of contamination is very difficult indeed. However, systematic studies detecting the main harmful compounds are needed to define alternatives to substitute or limit their use. From the agricultural chemicals, carbedazim has been identified as a potential endocrine disruptor as shown in a human ovarian granulosa-like tumor cell line [119]. Chlorinated pesticides like dichlorodiphenyltrichloroethane (DDT) and hexachlorobenzene (HCB) in sera from women submitted to IVF have been related to impaired embryo implantation [120]. Methoxychlor, a substitute for DDT, is a pesticide linked to female reproductive dysfunction by hypermethylation in estrogen receptors, and phosphatase and tensin homolog (PTEN) signaling, which is involved in follicular activation [121].

Plasticizers, mostly phthalates used to increase the flexibility of materials like construction products, cosmetics, medical devices or to coat medication, encompass another important group of environmental contaminants. These chemicals do not accumulate in human follicular fluid [122]. However, prenatal exposure to phthalates may lead to estrogenic or anti-androgenic effects in girls at pubertal age affecting uterine volume [123]. It can be expected that impaired steroidogenesis will lead to impaired oocyte development.

PCBs and dioxins can disturb female fertility [124] and embryo development $[125,126]$. Exposure in utero to these compounds delayed reproductive development especially in girls [127]. There is heightened investment as well as apprehension on nanoparticle research. For example, nanoparticles containing silver are able to inhibit porcine oocyte maturation [94], but knowledge on the possible effects and endocrine interactions on human reproduction is limited [128]. The use of in vitro models will help to predict the risks of these compounds on 
Table 1 Toxic compounds tested in vitro using bovine and porcine models

\begin{tabular}{|c|c|c|c|c|c|c|c|c|c|c|c|c|c|c|}
\hline \multirow[t]{2}{*}{ Environmental } & \multicolumn{2}{|l|}{ Species } & \multicolumn{3}{|l|}{ Exposure } & \multicolumn{2}{|l|}{ Cumulus } & \multicolumn{3}{|l|}{ Oocytes } & \multicolumn{4}{|l|}{ Embryos } \\
\hline & Bovine & Porcine & IVM & IVF & IVC & Viability & Expansion & Viability & MII & $\begin{array}{l}\text { Fertilization/ } \\
\text { Activation }\end{array}$ & 2-4 cells & Blast & $\mathrm{N}$ nuclei & Ploidy \\
\hline Anabasine [86] & & 86 & 86 & & & & 86 & & & & & & & \\
\hline Atrazine $[17,87,88]$ & 17,87 & 88 & $17,87,88$ & 87 & & 17,88 & & & 17,88 & 87 & & 87 & & \\
\hline Benzo(a)pyrene [15] & 15 & & 15 & 15 & & 15 & & & 15 & 15 & & & & \\
\hline Benzyl butyl phthalate [89] & & 89 & 89 & & & & 89 & & 89 & & & & & \\
\hline Cadmium $[15,17,86]$ & 15,17 & 86 & $15,17,86$ & 15 & & 15,17 & 86 & & 15,17 & 15 & & & & \\
\hline Carbedazim [15] & 15 & & 15 & 15 & & 15 & & & 15 & 15 & & & & \\
\hline 4-Chloro-3-methyl phenol [89] & & 89 & 89 & & & & 89 & & 89 & & & & & \\
\hline Cotinine $[17,86]$ & 17 & 86 & 17,86 & & & 17 & 86 & & 17 & & & & & \\
\hline Cycloheximide $[15,17]$ & 15,17 & & 15,17 & 15 & & 15,17 & & & 15,17 & 15 & & & & \\
\hline DEHP $[89,90]$ & 90 & 89 & 89,90 & & & & 89 & & 89,90 & & 90 & 90 & & \\
\hline Diazinon $[88,91]$ & & 88,91 & 88,91 & 91 & 91 & 88 & & 91 & 88 & 91 & 91 & 91 & & \\
\hline DDT [92] & 92 & & 92 & & & & & & 92 & 92 & 92 & 92 & 92 & \\
\hline Fenoxaprop-ethyl [88] & & 88 & 88 & & & 88 & & & 88 & & & & & \\
\hline Hexachlorocyclohexane [92] & 92 & & 92 & & & & & & 92 & 92 & 92 & 92 & 92 & \\
\hline Lindane [15] & 15 & & 15 & 15 & & 15 & & & 15 & 15 & & & & \\
\hline Malathion $[88,91]$ & & 88,91 & 88,91 & 91 & 91 & 88 & & 91 & 88 & 91 & 91 & 91 & & \\
\hline Methoxychlor [92] & 92 & & 92 & & & & & & 92 & 92 & 92 & 92 & 92 & \\
\hline MEHP $[17,90,93]$ & $17,90,93$ & & $17,90,93$ & & & 17 & 93 & & $17,90,93$ & & 90 & 90 & & \\
\hline Nanoparticles Au-Ag [94] & & 94 & 94 & & & & 94 & & 94 & & & & & \\
\hline Nicotine $[17,86,95,96]$ & $17,95,96$ & 86 & $17,86,95,96$ & 95 & 95 & 17 & 86,95 & & $17,95,96$ & 95 & 95,96 & 95,96 & 96 & 96 \\
\hline PCB mixtures [19,97-102] & $97-99$ & $19,100-102$ & 19,97-101 & 101 & 102 & $19,99,100$ & 19,100 & 19 & $19,97-100$ & $19,97,98,100,101$ & $19,97,98,101$ & $\begin{array}{l}19,97,98 \\
100-102\end{array}$ & $98,101,102$ & \\
\hline 4-tert-octylphenol [103] & 103 & & 103 & & & & & & 103 & 103 & 103 & 103 & 103 & \\
\hline \multicolumn{15}{|l|}{ Food } \\
\hline Bisphenol A [89] & & 89 & 89 & & & & 89 & & 89 & & & & & \\
\hline a-Chaconine [104] & 104 & & 104 & 104 & 104 & & & & & & 104 & 104 & & \\
\hline Daidzein [105] & & 105 & 105 & & & & 105 & & 105 & 105 & 105 & 105 & & \\
\hline Deoxynivalenol [106-108] & & $106-108$ & $106-108$ & & 106 & 108 & 108 & & $106-108$ & 108 & 107,108 & 107,108 & 107,108 & 107,108 \\
\hline Flavanones [109] & & 109 & 109 & & & & 109 & & 109 & 109 & 109 & 109 & & \\
\hline Genistein [15] & 15 & & 15 & 15 & & 15 & & & 15 & 15 & & & & \\
\hline
\end{tabular}


Table 1 Toxic compounds tested in vitro using bovine and porcine models (Continued)

\begin{tabular}{|c|c|c|c|c|c|c|c|c|c|c|c|c|}
\hline a-Solanine [104] & 104 & & 104 & 104 & 104 & & & & 104 & 104 & & \\
\hline Solanidine-N-oxide [104] & 104 & & 104 & 104 & 104 & & & & 104 & 104 & & \\
\hline Zearelanone $[107,110,111]$ & 110,111 & 107 & $107,110,111$ & & & & $107,110,111$ & & 107,110 & 107,110 & 107 & 107 \\
\hline a-zearalenol $[106,107,112]$ & & $106,107,112$ & 106,107 & & 106 & & 106,107 & & 107,112 & 107,112 & 107,112 & 107 \\
\hline$\beta$-zearalenol $[106,107]$ & & 106,107 & & & & & 106,107 & & 107 & 107 & 107 & 107 \\
\hline \multicolumn{13}{|l|}{ Drugs } \\
\hline Busulfan [15] & 15 & & 15 & 15 & 15 & & 15 & 15 & & & & \\
\hline Diethylstilbestro I [15,17] & 15,17 & & 15,17 & 15 & 15,17 & & 15,17 & 15 & & & & \\
\hline 17ß-Estradiol [17,103] & 17,103 & & 17,103 & & 17 & & 17,103 & 103 & 103 & 103 & 103 & \\
\hline lonomycin [15] & 15 & & 15 & 15 & 15 & & 15 & 15 & & & & \\
\hline Ketoconazole [15] & 15 & & 15 & 15 & 15 & & 15 & 15 & & & & \\
\hline Methyl acetoacetate [15] & 15 & & 15 & 15 & 15 & & 15 & 15 & & & & \\
\hline Mifepristone [15] & 15 & & 15 & 15 & 15 & & 15 & 15 & & & & \\
\hline Nocodazole $[15,17]$ & 15,17 & & 15,17 & 15 & 15,17 & & 15,17 & 15 & & & & \\
\hline Okadaic acid [95] & 95 & & 95 & & & 95 & 95 & & & & & \\
\hline Piperazine [17] & 17 & & 17 & & 17 & & 17 & & & & & \\
\hline Swainsonine [113] & 113 & & 113 & 113 & 113 & & & & 113 & 113 & 113 & \\
\hline Taxol [95] & 95 & & 95 & & & 95 & 95 & & & & & \\
\hline \multicolumn{13}{|l|}{ Cosmetics } \\
\hline Butylparaben [15] & 15 & & 15 & 15 & 15 & & 15 & 15 & & & & \\
\hline 9-cis-Retinoic acid [114] & 114 & & 114 & & & & & & 114 & 114 & & \\
\hline Retinoic acid [17] & 17 & & 17 & & 17 & & 17 & & & & & \\
\hline \multicolumn{13}{|l|}{ Occupational } \\
\hline Acrylamide [17] & 17 & & 17 & & 17 & & 17 & & & & & \\
\hline
\end{tabular}


oocyte maturation and subsequent fertilization and embryo development.

Nicotine and other chemicals present in cigarette smoke, e.g. anabasine, benzo(a)pyrene, cadmium and cotidine, are environmental contaminants that have not only been demonstrated to cause neoplasia but also reproductive failure. Bordel et al. [129] have shown that nicotine induces apoptosis in ovarian follicles. Different from phthalates, chemicals present in cigarette smoke can accumulate in follicular fluid. The main tobacco related compounds benzo(a)pyrene, cadmium, and cotidine for instance were found in human follicular fluid and related to fertility failure [130,131]. Cigarette smoke also leads to reduced concentrations of anti-Müllerian hormone (AMH) in follicular fluid, which may negatively impact oocyte development [132]. More recently, it has been reported that in utero exposure to cigarette smoke can impair endocrine signaling in female fetuses and can inhibit the progression of early ovarian follicle development [133]. Furthermore cotinine, a nicotine metabolite, has been detected in follicular fluid from passive smokers [134,135], which is a warning also for non-smoker women constantly exposed to cigarette smoke.

\section{Food toxic compounds}

Together with environmental toxic compounds, exposure to food contaminants can also affect animal and human reproductive function. Food toxic agents can be of natural origin, as mycotoxins, and can be synthetic, for instance BPA. While BPA is known as an endocrine disruptor, mycotoxins have the ability to act either as endocrine disruptors or as endocrine active substances [136].

Mycotoxins like deoxynivalenol (DON), zearalenone (ZEA) and its metabolites (alpha- and beta-zearalenol) can cause reproductive failure. Although DON has been associated with gastroenteritis [137], there are reports on the reproductive effect of this mycotoxin in domestic animals [138]. Abundant knowledge is available on the estrogenic effect of ZEA in human and domestic animals [136]. However, there are many of the so-called emerging mycotoxins, e.g. enniatins, alternariol and beauverecin, that need to be screened on their action on female reproduction. For example, it is known that alternariol at high concentrations impairs progesterone synthesis in porcine granulosa cells [139]. Beauvericin might be another potential mycotoxin with reproductive effects since recently this mycotoxin was advocated to be an antitumor candidate due to its role in the inhibition of MAP kinase phosphorilation [140]. Although BPA does not accumulate in follicular fluid [122], it negatively affects human oocyte maturation in vitro by disturbing spindle architecture and chromosome organization [141]. However, there is a lack of data revealing if BPA affects human oviduct, placenta and pubertal development [142].
Alpha-chaconine and alpha-solanine are natural glycoalkaloids, natural pesticides, found in potatoes. These secondary metabolites are produced by potatoes when threatened by pathogens or insects. This means that injuries to some vegetables like potatoes can pose a risk to human health [143]. Besides this, most information related to female reproduction, however, is limited to studies in rats [144] and mice [145]. Phytoestrogens, with isoflavones and flavanones as the most studied are also investigated for their effects on human reproduction. Genistein is found in soybeans. Although isoflavones like genistein do not impair murine oocyte maturation [146], this phytoestrogen, as well as daidzein, can affect the development of mice reproductive organs [147]. It has been shown also that although daidzein does not affect porcine oocyte maturation, it is able to disturb progesterone secretion by $\mathrm{cu}-$ mulus cells [105]. Recently, Solak et al. [109] also showed that naringenin and 8-prenyl-naringenin impaired porcine oocyte maturation by different mechanisms. Besides these solid evidences of the risks of phytoestrogens, and the fact that human consumption of these compounds is high, epidemiological data in human are scarce and more studies using animal models are crucial as every day more phytoestrogens are recognized or included as therapeutic compounds [148].

In a sophisticated cohort study in France, Chan-Hon-Tong et al. [149] acquired detailed information on dietary exposure to potential contaminants in women before pregnancy and at the third trimester of pregnancy. Although exposure before pregnancy appeared higher than at the end of pregnancy, the fetus still can be exposed to contaminants like mycotoxins, acrylamide and PCBs. Besides, exposure before pregnancy may also impair the ability of a woman to conceive naturally, thus requiring ART.

\section{Drugs, cosmetics and occupational toxic compounds}

Research on the endocrine effect of drugs, cosmetics and occupational toxic compounds is available but more limited. Probably because some adverse effects are already expected, like the use of antineoplasic drugs, or due the fact that exposure to occupational toxicants is already under strict regulation. However, in some developing countries children are constantly exposed to parasites, requiring a routinely based administration of drugs such as antifungals, which may act also as endocrine disruptors [150]. Maternal anemia or risks of perinatal death can be caused by helminthic infestation, which must be treated with anthelmintic drugs. But, such drugs may also have embryotoxic effects [151].

In humans a relatively constant exposure to drugs is inevitable, either by choice (contraceptives) or to treat diseases (chemotherapeutic, antiparasitic, antidepressants or antiepileptic agents) which, after chronic use, may affect fertility or embryo development [152-154]. It is well 
known that many chemotherapeutic agents, particularly alkylating agents, impair fertility not because of their cytotoxic characteristics but also by leading to premature ovarian failure or insufficiency, affecting oocyte reserve, activation and growth [155]. Other drugs like busulfan, diethylstilbestrol, $17 \beta$-estradiol, mifepristone, ketoconazole, piperazine, methyl acetoacetate, okadaic acid and taxol are endocrine disruptors. Although in vitro data in bovine and porcine show the risks that these compounds bring to oocyte maturation and fertilization, little is known about their effect on human oocyte maturation and fertilization.

Cosmetics bring concerns because of their increase in the market and augmented use by humans, including children. Among them, compounds present in UV-filters like benzophenone are endocrine disruptors that have been detected in human serum [156]. Topical use of retinoic acid has been included as a hazard for its teratogenic risk, but such exposure is too low when compared to the oral administration of vitamin A [157]. Besides, Tahaei et al. [158] showed that treatment of murine oocyte with retinoic acid during IVM has positive impact on maturation rate and subsequent embryo development after IVF.

Also, occupational toxicants have been analyzed for effects on reproduction. Acrylamide has been characterized as an occupational toxicant, once it is used to synthesize polyacrylamides, one of the compounds used in gels for electrophoresis. Due to severe legislation to protect researchers and analysts who work with this compound, most risks are avoided. However, this compound still harms human health since it is also a food toxicant. Dimethylene glycol monobutyl ether (DGBE) is present in latex paints, but is not toxic for rats after 10 weeks of exposure [159]. However, humans who by their profession may be exposed to these compounds for years might be affected. Pesticides, including insecticides and rodenticides, also act as occupational toxicants, affecting adults and children [160]. Even at low concentrations, chronic exposure to these compounds affects endocrine activity [161].

\section{Final remarks}

Many couples apply to ART because of fertility problems and more than one fifth of the causes of sub/infertility in female are unknown. There is compelling evidence that fertility problems are related to the exposure to different sources of contaminants, among them dietary and environmental appearing as a great concern. Some of the identified chemicals can affect the oocyte already during maturation. If the oocyte does not follow an apoptotic pathway, there is still the risk that fertilization and subsequent embryo development will be somehow affected. Furthermore, when ART is necessary, patients should be advised about the environmental and dietary contaminants not only because of metabolic diseases, but also to prevent exposure to hazardous chemicals.

To identify the effect of such dietary and environmental compounds, cell lines have been used as an important screening tool. However, a cell line will not always mimic gametes during a critical phase of maturation, which requires specific biochemical changes. It is possible to apply reliable and more complex screening methods, as well as decrease the number of laboratory animals, by using bovine or porcine as models for IVM, IVF and embryo production in vitro. Obviously the bovine/porcine model will not replace rapid and massive screenings with cell lines, and cannot completely eliminate in vivo studies with rodents. Although, the research material will be obtained from healthy animals that entered the food chain and no extra facilities are necessary to house animals, bovine and porcine IVM/IVF models have certain disadvantages that should be considered when applied to test potential toxic compounds. For instance, the origin of slaughterhousederived materials (ovaries) is often unknown such as age, reproductive status, possible reproductive disorders or stressful conditions. To overcome this, Ovum Pick-Up (OPU) from donors with known background can provide a solution. Even though cattle oocyte development is rather similar to that of humans, in in vivo studies the porcine appears as a good model for transgenerational research since it is a monogastric species with a gastrointestinal tract similar to that of humans. Overweighing supposed risks of certain chemicals should be avoided. However, human beings are daily exposed to different contaminants. Even though exposure may occur at extremely low concentrations of each contaminant, chronic multi-exposure should be taken into account, and epigenetic changes affecting embryo development must be considered.

\section{Competing interests}

The authors declare that they have no competing interests.

\section{Authors' contributions}

RRS and EJS participated in the survey of the data. RRS, EJS and BAJR conceived the study, and participated in its design and wrote the manuscript. All authors read and approved the final manuscript.

\section{Acknowledgements}

BR was supported by EU FP7 Anistem PIAPP-GA-2011-286264; EpiHealthNet PITN-GA-2013-317146.

\section{Author details}

${ }^{1}$ Institute for Risk Assessment Sciences, Faculty of Veterinary Medicine, Utrecht University, P.O Box 80152, 3508 TD Utrecht, The Netherlands.

'Laboratory of Wild Animal Biology and Medicine, Federal University of Pará, Rua Augusto Corrêa, Campus Básico, CEP 66075-110 Belém, Pará, Brazil.

${ }^{3}$ Department of Farm Animal Health, Utrecht University, Yalelaan 104, 3584 CM Utrecht, The Netherlands. ${ }^{4}$ Department of Equine Sciences, Faculty of Veterinary Medicine, Utrecht University, Yalelaan 104, 3584 CM Utrecht, The Netherlands.

Received: 22 July 2014 Accepted: 5 November 2014 Published: 26 November 2014 


\section{References}

1. European Food Safety Authority (EFSA): Scientific Opinion on the hazard assessment of endocrine disruptors: scientific criteria for identification of endocrine disruptors and appropriateness of existing test methods for assessing effects mediated by these substances on human health and the environment. EFSA J 2013, 11:3132.

2. Dokras A, Witchel SF: Are young adult women with polycystic ovary syndrome slipping through the healthcare cracks? Endocrinol Metab 2014, 99:1583-1585.

3. Turner-McGrievy G, Davidson CR, Billings DL: Dietary intake, eating behaviours, and quality of life in women with polycystic ovary syndrome who are trying to conceive. Hum Fertil 2014, 12:1-6,

4. Matzuk MM, Lamb DJ: The biology of infertility: research advances and clinical challenges. Nat Med 2008, 14:1197-1213.

5. Kandaraki E, Chatzigeorgiou A, Livadas S, Palioura E, Economou F, Koutsilieris M, Palimeri S, Panidis D, Diamanti-Kandarakis E: Endocrine disruptors and polycystic ovary syndrome (PCOS): elevated serum levels of bisphenol A in women with PCOS. J Clin Endocrinol Metab 2011, 96:480-484

6. Pau CT, Keefe CC, Welt CK: Cigarette smoking, nicotine levels and increased risk for metabolic syndrome in women with polycystic ovary syndrome. Gynecol Endocrinol 2013, 29:551-555.

7. Bremer S, Pellizzer C, Hoffmann S, Seidle T, Hartung T: The development of new concepts for assessing reproductive toxicity applicable to large scale toxicological programmes. Curr Pharm Des 2007, 13:3047-3058.

8. Spielmann $\mathrm{H}$ : The way forward in reproductive/developmental toxicity testing. Altern Lab Anim 2009, 37:641-656.

9. Ménézo YJ, Hérubel F: Mouse and bovine models for human IVF. Reprod Biomed Online 2002, 4:170-175.

10. Piersma AH: Innovations in testing strategies in reproductive toxicology. Methods Mol Biol 2013, 16:295-305.

11. Piersma $A H$, Bosgra $S$, van Duursen $M B$, Hermsen $S A$, Jonker $L R$, Kroese $E D$, van der Linden SC, Man H, Roelofs MJ, Schulpen SH, Schwarz M, Uibel F, van Vugt-Lussenburg BM, Westerhout J, Wolterbeek AP, van der Burg B: Evaluation of an alternative in vitro test battery for detecting reproductive toxicants. Reprod Toxicol 2013, 38:53-64.

12. Nohynek GJ, Borgert CJ, Dietrich D, Rozman KK: Endocrine disruption: fact or urban legend? Toxicol Lett 2013, 16:295-305.

13. Sirard MA: Factors affecting oocyte and embryo transcriptomes. Reprod Domest Anim 2012, 47:148-155.

14. Pocar P, Brevini TAL, Fischer B, Gandolfi F: The impact of endocrine disruptors on oocyte competence. Reproduction 2003, 125:313-325.

15. Lazzari G, Tessaro I, Crotti G, Galli C, Hoffmann S, Bremer S, Pellizzer C: Development of an in vitro test battery for assessing chemical effets of bovine germ cells under the ReProtect umbrella. Toxicol Appl Pharmacol 2008, 233:360-370.

16. Luciano AM, Franciosi F, Lodde V, Corbani D, Lazzari G, Crotti G, Galli C, Pellizzer C, Bremer S, Weimer M, Modina SC: Transferability and inter-laboratory variability assessment of the in vitro bovine oocyte maturation (IVM) test within ReProTect. Reprod Toxicol 2010, 30:81-88.

17. Beker van Woudenberg AB, Gröllers-Mulderij M, Snel C, Jeurissen N, Stierum R, Wolterbeek A: The bovine oocyte in vitro maturation model: a potential tool for reproductive toxicology screening. Reprod Toxicol 2012, 34:251-260.

18. Ulf M: Can farm animals help to study endocrine disruption. Domest Anim Endocrinol 2005, 39:430-435.

19. Campagna C, Ayotte P, Sirard MA, Arsenault G, Laforest JP, Bailey JL: Effect of an environmentally relevant metabolized organochlorine mixture on porcine cumulus-oocyte complexes. Reprod Toxicol 2007, 23:145-152.

20. Schoevers EJ, Santos RR, Colenbrander B, Fink-Gremmels J, Roelen BA: Transgenerational toxicity of zearalenone in pigs. Reprod Toxicol 2012, 34:110-119.

21. Lorenzetti S, Altieri I, Arabi S, Balduzzi D, Bechi N, Cordelli E, Galli C, Letta F, Modina SC, Narciso: Innovative non-animal testing strategies for reproductive toxicology: the contribution of Italian partners within the EU project ReProTect. Ann Ist Super Sanita 2011, 47:429-444.

22. European Union: Directive 2010/63/EU of the European Parliament and of the Council of 22 September 2010 on the protection of animals used ofr scientific purposes. OJEU L 2010, 276:33.

23. Wassarman PM, Litscher ES: Influence of the zona pellucida of the mouse egg on folliculogenesis and fertility. Int J Dev Biol 2012, 56:833-839.
24. Sanchez F, Smitz J: Molecular control of oogenesis. Biochim Biophys Acta 1822, 2012:1896-1912.

25. Driancourt MA: Regulation of ovarian follicular dynamics in farm animals. Implications for manipulation of reproduction. Theriogenology 2001, 55:1211-1239.

26. Baerwald AR, Adams GP, Pierson RA: Ovarian antral folliculogenesis during the human menstrual cycle: a review. Hum Reprod Update 2012, 18:73-91.

27. Evans AC, Mossa F, Walsh SW, Scheetz D, Jimenez-Krassel F, Ireland JL, Smith GW, Ireland JJ: Effects of maternal environment during gestation on ovarian folliculogenesis and consequences for fertility in bovine offspring. Reprod Domest Anim 2012, 47:31-37.

28. Coticchio G, Dal-Canto M, Guglielmo MC, Mignini-Renzini M, Fadini R: Human oocyte maturation in vitro. Int J Dev Biol 2012, 56:909-918.

29. Li R, Albertini DF: The road of maturation: somatic cell interaction and self-organization of the mammalian oocyte. Nat Rev Mol Cell Biol 2013, 14:141-152.

30. Cortvrindt RG, Smitz JE: Follicle culture in reproductive toxicology: a tool for in vitro testing of ovarian function. Hum Reprod Update 2002, 8:243-254.

31. Tan JH, Wang HL, Sun XS, Liu XS, Sui HS, Zhang J: Chromatin configurations in the germinal vesicle of mammalian oocytes. Mol Hum Reprod 2009, 15:1-9.

32. Sirard MA: Follicle environment and quality of in vitro matured oocytes. J Assist Reprod Genet 2011, 28:483-488.

33. Hunter AG, Moor RM: Stage-dependent effects of inhibiting ribonucleic acids and protein synthesis on meiotic maturation of bovine oocytes in vitro. J Dairy Sci 1987, 70:1646-1652.

34. Motlik J, Fulka J: Factors affecting meiotic competence in pig oocytes. Theriogenology 1986, 25:87-96.

35. Cha KY, Chian RC: Maturation in vitro of immature human oocytes for clinical use. Hum Reprod Update 1998, 4:103-120.

36. Schultz RM, Wassarman PM: Biochemical studies of mammalian oogenesis: protein synthesis during oocyte growth and meiotic maturation in the mouse. J Cell Sci 1977, 24:167-194.

37. Bilodeau-Goeseels S: Cows are not mice: the role of cyclic AMP, phosphodiesterases, and adenosine monophosphate-activated protein kinase in the maintenance of meiotic arrest in bovine oocytes. Mol Reprod Dev 2011, 78:734-743.

38. Ueda Y, Okano M, Willams C: Roles for Dnmt3b in mammalian development: a mouse model for the ICF syndrome. Development 2006, 133:631-647.

39. Reik W, Dean W, Walter J: Epigenetic reprogramming in mammalian development. Science 2001, 293:1089-1093.

40. Sylvestre EL, Robert C, Pennetier S, Labrecque R, Gilbert I, Dufort I, Léveillé, Sirard MA: Evolutionary conservation of the oocyte transcriptome among vertebrates and its implications for understanding human reproductive function. Mol Hum Reprod 2013, 19:369-379.

41. Jarell VL, Day BN, Prather RS: The transition from maternal to zygotic control of development occurs during the 4-cell stage in the domestic pig, Sus scrofa: quantitative and qualitative aspects of protein synthesis. Biol Reprod 1991, 44:62-68.

42. Frei RE, Schultz GA, Church RB: Qualitative and quantitative changes in protein synthesis occur at the 8-16-cell stage of embryogenesis in the cow. J Reprod Fertil 1989, 86:637-641.

43. Levey RH, Stull GB, Brinster RL: Poly(A) and synthesis of polyadenylated RNA in the preimplantation mouse embryo. J Exp Zool 1978, 203:351-360.

44. Sturmey RG, Reis A, Leese HJ, McEvoy TG: Role of fatty acids in energy provision during oocyte maturation and early embryo development. Reprod Dom Anim 2009, 44:50-58.

45. McEvoy TG, Coull GD, Broadbent PJ, Hutchinson JSM, Speake BK: Fatty acid composition of lipids in immature cattle, pig and sheep oocytes with intact zona pellucida. J Reprod Fert 2000, 118:163-170.

46. Haggarty P, Wood M, Ferguson E, Hoad G, Srikantharajah A, Milna E, Hamilton M, Bhattacharya S: Fatty acids metabolism in human preimplantation embryos. Hum Reprod 2006, 21:766-773.

47. Sturmey RG, Leese HJ: Energy metabolism in pig oocytes and early embryos. Reproduction 2003, 126:197-204.

48. Nagashima $H$, Hiruma K, Saito H, Tomii R, Ueno S, Nakayama N, Matsunari $H_{\text {, }}$ Kurome M: Production of live piglets following cryopreservation of embryos derived from in vitro-matured oocytes. Biol Reprod 2007. 76:900-905. 
49. Mihalik J, Rehák P, Koppel J: The influence of insulin on the in vitro development of mouse and bovine embryos. Physiol Res 2000, 49:347-354

50. Rodriguez-Osorio N, Wang H, Rupinski J, Bridges SM, Memili E: Comparative functional genomics of mammalian DNA methyltransferases. Reprod Biomed Online 2010, 20:243-255.

51. Misirlioglu M, Page GP, Sagirkaya H: Dynamic of global transcriptome in bovine matured oocytes and preimplantation embryos. Proc Natl Acad Sci U S A 2006, 103:18905-18910.

52. Vassena R, Dee Schramm R, Latham KE: Species-dependent expression patterns of DNA methyltransferase genes in mammalian oocytes and preimplantation embryos. Mol Reprod Dev 2005, 133:430-436.

53. Huntriss J, Hinkins $M$, Oliver B: Expression of mRNAs for DNA methyltransferases and methyl-CpG-binding proteins in the human female germ line, preimplantation embryos and embryonic stem cells. Mol Reprod Dev 2004, 67:323-336.

54. Otoi T, Yamamoto K, Koyama N, Tachikawa S, Suzuki T: Bovine oocyte diameter in relation to developmental competence. Theriogenology 1997, 48:769-774.

55. Durinzi KL, Saniga EM, Lanzendorf SE: The relationship between size and maturation in vitro in the unstimulated human oocyte. Fertil Steril 1995, 63:404-406

56. Serta RT, Michalopoulos J, Seibel MM, Kiessling AA: The developmental potential of mouse oocytes matured in serum-free culture conditions. Hum Reprod 1995, 10:1810-1815.

57. Sanfins A, Lee GY, Plancha CE, Overstrom EW, Albertini DF: Distinctions in meiotic spindle structure and assembly during in vitro and in vivo maturation of mouse oocytes. Biol Reprod 2003, 69:2059-2067.

58. Moon JH, Jee BC, Ku SY, Suh CS, Kim SH, Choi YM, Kim JG, Moon SY: Spindle positions and their distributions in in vivo and in vitro matured mouse oocytes. Hum Reprod 2005, 20:2207-2210.

59. Laurincik J, Rath D, Niemann H: Differences in pronucleus formation and first cleavage following in vitro fertilization between pig oocytes matured in vivo and in vitro. J Reprod Fertil 1994, 102:227-284

60. Wang WH, Abeydeera LR, Prather RS, Day BN: Morphologic comparison of ovulated and in vitro-matured porcine oocytes, with particular reference to polyspermy after in vitro fertilization. Mol Reprod Dev 1998, 49:308-316.

61. Rizos D, Ward F, Duffy P, Boland MP, Lonergan P: Consequences of bovine oocyte maturation, fertilization or early embryo development in vitro versus in vivo: implications for blastocyst yield and blastocyst quality. Mol Reprod Dev 2002, 61:234-248.

62. Van de Leemput EE, Vos PL, Zeinstra EC, Bevers MM, van der Weijden GC, Dieleman SJ: Improved in vitro embryo development using in vivo matured oocytes from heifers superovulated with a controlled preovulatory surge. Theriogenology 1999, 52:335-349.

63. Jones GM, Trounson AO, Gardner DK, Kausche A, Lolatgis N, Wood C: Evolution of a culture protocol for successful blastocyst development and pregnancy. Hum Reprod 1998, 13:169-177.

64. Cekleniak NA, Combelles CM, Ganz DA, Fung J, Albertini DF, Racowsky C: A novel system for in vitro maturation of human oocytes. Fertil Steril 2001, 75:1185-1193.

65. Harlow GM, Quinn P: Development of preimplantation mouse embryos in vivo and in vitro. Aust J Biol Sci 1982, 35:187-193.

66. Papaioannou VE, Ebert KM: The preimplantation pig embryo: cell number and allocation to trophectoderm and inner cell mass of the blastocyst in vivo and in vitro. Development 1988, 102:793-803.

67. Rath D, Niemann H, Torres CR: In vitro development to blastocysts of early porcine embryos produced in vivo or in vitro. Theriogenology 1995, 43:913-926.

68. Christians E, Davis AA, Thomas SD, Benjamin IJ: Maternal effect of Hsf1 on reproductive success. Nature 2000, 407:693-694.

69. Anderson JE, Matteri RL, Abeydeera LR, Day BN, Prather RS: Cyclin B1 transcript quantitation over the maternal to zygotic transition in both in vivo-and in vitro-derived 4-cell porcine embryos. Biol Reprod 1999, 61:1460-1467.

70. Prather RS: Nuclear control of early embryonic development in domestic pigs. J Reprod Fertil Suppl 1993, 48:17-29.

71. Braude $P$, Bolton $V$, Moore $S$ : Human gene expression first occurs between the four- and eight-cell stages of preimplantation development. Nature 1988, 332:459-461.
72. Bouniol-Baly C, Nguyen E, Besombes D, Debey P: Dynamic organization of DNA replication in one-cell mouse embryos: relationship to transcriptional activation. Exp Cell Res 1997, 236:201-211.

73. Petro EM, Leroy JL, Van Cruchten SJ, Covaci A, Jorssen EP, Bols PE: Endocrine disruptors and female fertility: focus on (bovine) ovarian follicular physiology. Theriogenology 2012, 78:1887-1900

74. Swindle MM, Makin A, Herron AJ, Clubb FJ Jr, Frazier KS: Swine as models in biomedical research and toxicology testing. Vet Pathol 2012, 49:344-356.

75. Brehm MA, Jouvet N, Greiner DL, Shultz LD: Humanized mice for the study of infectious diseases. Curr Opin Immunol 2013, 25:428-435.

76. Shen H, Henkelmann B, Rambeck WA, Mayer R, Wehr U, Schramm KW: The predictive power of the elimination of dioxin-like pollutants from pigs: an in vivo study. Environ Int 2012, 38:73-78.

77. Ulaszewska MM, Zuccato E, Davoli E: PCDD/Fs and dioxin-like PCBs in human milk and estimation of infants' daily intake: a review. Chemosphere 2011, 83:774-782.

78. Müller JC, Imazaki PH, Boareto AC, Lourenço EL, Golin M, Vechi MF, Lombardi NF, Minatovicz BC, Scippo ML, Martino-Andrade AJ, Dalsenter PR: In vivo and in vitro estrogenic activity of the antidepressant fluoxetine. Reprod Toxicol 2012, 34:80-85.

79. ' $t$ Jong GW, Einarson T, Koren G, Einarson A: Antidepressant use in pregnancy and persistent pulmonary hypertension of the newborn (PPHN): a systematic review. Reprod Toxicol 2012, 34:293-297.

80. Kjaergaard MI, Parner ET, Vestergaard M, Sorensen MJ, Olsen J, Christensen J, Bech BH, Pedersen LH: Prenatal antidepressant exposure and risk of spontaneous abortion - a population-based study. PLOS One 2013, 28:e72095.

81. Fong PP, Ford AT: The biological effects of antidepressants on the molluscs and crustaceans: a review. Aquat Toxicol 2014, 151:4-13.

82. Hernández-Diaz S, Su YC, Mitechll AA, Kelley KE, Calafat AM, Hauser R: Medications as a potential source of exposure to phthalates among women of childbearing age. Reprod Toxicol 2013, 37:1-5.

83. Cheng $L$, Jin $C$, Zhang $Y$ : Investigation of variations in the acrylamide and $\mathrm{N}(\mathcal{E})$-(carboxymethyl) lysine contents in cookies during baking. $J$ Food Sci 2014, 79:1030-1038.

84. Erkekoglu P, Baydar T: Toxicity of acrylamide and evaluation of its exposure in baby foods. Nutr Res Rev 2010, 23:323-333.

85. Duarte-Salles T, von Stedingk H, Granum B, Gützkow KB, Rydberg P, Törngvist M, Mendez MA, Brunborg G, Brantsaeter AL, Meltzer HM, Alexander J, Haugen M: Dietary acrylamide intake during pregnancy and fetal growth-results from the Norwegian mother and child cohort study (MoBa). Environ Health Perspect 2013, 121:374-379.

86. Vrsanska S, Nagyová E, Mlynarciková A, Ficková M, Kolena J: Components of cigarette smoke inhibit expansion of oocyte cumulus complexes from porcine follicles. Physiol Res 2003, 52:383-387.

87. Graves JE, Richardson ME, Bernard RS, Camper ND, Bridges WC: Atrazine effects on in vitro maturation and in vitro fertilization in the bovine oocyte. J Environ Sci Health 2002, 37:103-112.

88. Casas E, Bonilla E, Ducolomb Y, Betancourt M: Differenttial effects of herbicides atrazine and fenoxaprop-ethyl, and insecticides diazinon and malathion, on viability and maturation of porcine oocytes in vitro. Toxicol In Vitro 2010, 24:224-230.

89. Mlynarcikova A, Nagyova E, Fickova M, Scsuková S: Effects of selected endocrine disruptors on meiotic maturation, cumulus expansion, synthesis of hyaluronan and progesterone by procine oocyte-cumulus complexes. Toxicol In Vitro 2009, 23:371-377.

90. Grossman D, Kalo D, Gendelman M, Roth Z: Effect of di-(2-ethylhexyl) phthalate and mono-(2-ethylhexyl) phthalate on in vitro developmental competence of bovine oocytes. Cell Biol Toxicol 2012, 28:383-396

91. Ducolomb Y, Casas E, Valdez A, González G, Altamiro-Lozano M, Betancourt $M$ : In vitro effect of malathion and diazinon on oocytes fertilization and embryo development in porcine. Cell Biol Toxicol 2009, 25:623-633.

92. Alm H, Torner $\mathrm{H}$, Tiemann U, Kanitz W: Influence of organochlorine pesticides on maturation and postfertilization development of bovine oocytes in vitro. Reprod Toxicol 1998, 12:559-563.

93. Anas MKI, Suzuki C, Yoshioka K, Iwamura S: Effect of mono-(2-ethylhexyl) phthalate on bovine oocyte maturation in vitro. Reprod Toxicol 2003, 17:305-310. 
94. Tiedemann D, Taylor U, Rehbock C, Jakobi J, Klein S, Kues WA, Barcikowski S, Rath D: Reprotoxicity of gold, and gold-silver alloy nanoparticles on mammalian gametes. Analyst 2014, 139:931-942.

95. Li GP, Yang S, Liu Y, Sessions BR, White KL, Bunch TD: Nicotine combined with okadaic acid or taxol adversely affects bovine oocyte maturation and subsequent embryo development. Fertil Steril 2009, 92:798-805.

96. Liu Y, Li GP, White KL, Rickords LF, Sessions BR, Aston Kl, Bunch TD: Nicotine alters bovine oocyte meiosis and affects subsequent embryonic development. Mol Reprod Dev 2007, 74:1473-1482.

97. Krogenaes AK, Nafstad I, Skare JU, Farstad W, Hafne AL: In vitro reproductive toxicity of polychlorinated biphenyl congeners 153 and 126. Reprod Toxicol 1998, 12:575-580.

98. Pocar P, Perazzoli F, Risch M, Fischer B: In vitro reproductive toxicity of polychlorinated biphenyls: effects on oocyte maturation and developmental competence in cattle. Mol Reprod Dev 2001, 58:411-416.

99. Pocar P, Nestler D, Risch M, Fischer B: Apoptosis in bovine cumulus-oocyte complexes after exposure to polychlorinated biphenyl mixtures during in vitro maturation. Reproduction 2005, 160:857-868.

100. Campagna C, Sirard MA, Ayotte P, Bailey JL: Impaired maturation, fertilization, and embryonic development of porcine oocytes following exposure to an environmentally relevant organochlorine mixture. Biol Reprod 2001, 65:554-560.

101. Campagna C, Guillemette C, Paradis R, Sirard MA, Ayotte P, Bailey JL: An environmentally relevant organochlorine mixture impairs sperm function and embryo development in the porcine model. Biol Reprod 2002, 67:80-87.

102. Campagna $C$, Ayotte $P$, Sirard MA, Bailey JL: An environmentally relevant mixture of organochlorines, their metabolites and effects of preimplantation development of porcine embryos. Reprod Toxicol 2008, 25:361-366

103. Pocar P, Augustin R, Gandolfi F, Fischer B: Toxic effects of in vitro exposure fo p-tert-octylphenol on bovine oocyte maturation and developmental competence. Biol Reprod 2003, 39:462-468.

104. Wang S, Panter KE, Gaffield W, Evans RC, Bunch TD: Effects of steroidal glycoalkaloids from potatoes (Solanum tuberosum) on in vitro bovine embryo development. Anim Reprod Sci 2005, 85:243-250.

105. Galeati G, Vallorani C, Bucci D, Bernardini C, Tamanini C, Parmeggiani A, Spinaci M: Daidzein does affect progesterone secretion by pig culumus cells but it does not impair oocytes IVM. Theriogenology 2014, 74:451-457.

106. Alm H, Greising T, Brüssow KP, Torner $H$, Tiemann U: The influence of the mycotoxins deoxynivalenol and zearalenol on in vitro maturation of pig oocytes and in vitroculture of pig zygotes. Toxicol In Vitro 2002, 16:643-648

107. Malekinejad H, Schoevers EJ, DAemen IJ, Zijlstra C, Colenbrander B, Fink-Gremmels J, Roelen BA: Exposure of oocytes to the Fusarium toxins zearalenone and deoxynivalenol causes aneuploidy and abnormal embryo development in pigs. Biol Reprod 2007, 77:840-847.

108. Schoevers EJ, Fink-Gremmels J, Colenbrander B, Roelen BA: Porcine oocytes are most vulnerable to the mycotoxin deoxynivalenol during formation of the meiotic spindle. Theriogenology 2010, 74:968-978.

109. Solak KA, Santos RR, van den Berg M, Blaauboer BJ, Roelen BA, van Duursen MB: Narigenin (NAR) and 9-prenylnarigenin (8-PN) reduce the developmental competence of porcine oocytes in vitro. Reprod Toxicol 2014, in press. doi:10.1016/j.reprotox.2014.05.013

110. Tagaki M, Mukai S, Kuriyagawa T, Takagaki K, Uno S, Kokushi E, Otoi T, Budiyanto A, Shirasuna K, Miyamoto A, Kawamura O, Okamoto K, Deguchi E: Detection of zearalenone and its metabolites in naturally contaminated follicular fluid by using LC/MS/MS and in vitro effects of zearalenone on oocyte maturation in cattle. Reprod Toxicol 2008, 26:164-169.

111. Minervini F, Dell'Aquila ME, Maritato F, Minoia P, Visconti A: Toxic effects of the mycotoxin zearalenone and its derivatives on in vitro maturation of bovine oocytes and 17 beta-estradiol levels in mural granulosa cell cultures. Toxicol In Vitro 2001, 15:489-495

112. Wang H, Camargo Rodriguez O, Memili F: Mycotoxin alpha-zearalenol impairs the quality of preimplantation porcine embryos. $J$ Reprod Dev 2012, 58:338-343.

113. Wang S, Panter KE, Holyoak GR, Molyneux RJ, Liu G, Evans RC, Bunch TD: Development and viability of bovine preplacentation embryos treated with swainsonine in vitro. Anim Reprod Sci 1999, 17:19-29.

114. Gomez E, Royo L, Duque P, Carneiro G, Hidalgo C, Goyache F, Lorenzo PL, Alvarez I, Facal N, Díez C: 9-cis-Retinoic acid during in vitro maturation improves development of the bovine oocyte and increases midkine but not IGF-I expression in cumulus-granulosa cells. Mol Reprod Dev 2003, 66:247-255

115. Jin Y, Lin X, Miao W, Wu T, Shen H, Chen S, Li Y, Pan Q, Fu Z: Chronic exposure of mice to environmental endocrine-disrupting chemicals disturbs their energy metabolism. Toxicol Lett 2014, 225:392-400.

116. Ralston-Hooper KJ, Adamec J, Jannash A, Mollenhauer R, Ochoa-Acuña H, Sepúlveda MS: Use of GC x GC/TOF-MS and LC/TOF-MS for metabolomics analysis of Hyalella Azteca chronically exposed to atrazine and its primary metabolite, desethylatrazine. J App/ Toxicol 2011, 31:399-410.

117. Albright VC, Coats JR: Disposition of atrazine metabolites following uptake and degradation of atrazine in switchgrass. Int J Phytoremediation 2014, 16:62-72.

118. Barr DB, Ananth CV, Yan X, Lashley S, Smulian JC, Ledoux TA, Hore P Robson MG: Pesticide concentrations in maternal and umbilical cord sera and their relation to birth outcomes in a population of pregnant women and newborns in New Jersey. Sci Total Environ 2010, 15:790-795.

119. Morinaga H, Yanase T, Nomura M, Okabe T, Goto K, Harada N, Nawata H: A benzimidazole fungicide, benomyl, and its metabolite, carbedazim, induce aromatase activity in a human ovarian granulose-like tumor cell line (KGN). Endocrinology 2004, 145:1860-1869.

120. Mahalingaiah S, Missmer SA, Maity A, Williams PL, Meeker JD, Berry K, Ehrlich S, Perry MJ, Cramer DW, Hauser R: Association of hesachlorobenzene (HCB), dichlorodiphenyltrichloroethane (DDT), and dichlorodiphenyltrichloroethylene (DDE) with in vitro fertilization (IVF) outcomes. Environ Health Perspect 2012, 120:316-320.

121. Uzumcu M, Zama AM, Oruc E: Epigenetic mechanisms in the actions of endocrine-disrupting chemicals: gonadal effects and role in female reproduction. Reprod Domest Anim 2012, 47:338-347.

122. Krotz SP, Carson SA, Tomey C, Buster JE: Phthalates and bisphenol do not accumulate in human follicular fluid. J Assist Reprod Genet 2012, 29:773-777.

123. Hart R, Doherty DA, Frederiksen H, Keelan JA, Hickey M, Sloboda D, Pennell CE, Newnham JP, Skakkebaek NE, Main KM: The influence of antenatal exposure to phthalates on subsequent female reproductive development in adolescence: a pilot study. Reproduction 2014, 147:379-390.

124. Bastos AM, Souza Mdo C, Almeida Filho GL, Krauss TM, Pavesi T, Silva LE: Organochlorine compound levels in fertile and infertile women from Rio de Janeiro, Brazil. Arq Bras Endocrinol Metabol 2013, 57:346-353.

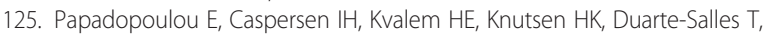
Alexander J, Meltzer HM, Kogevinas M, Brantsaeter AL, Haugen M: Maternal dietary intake of dioxins and polychlorinated biphenyls and birth sie in the Norwegian mother and child cohort study (MoBa). Environ Int 2013, 60:209-216.

126. Vafeiadi M, Vrijheid M, Fthenou E, Chalkiadaki G, Rantakokko P, Kiviranta H, Kyrtopoulos SA, Chatzi L, Kogevinas M: Persistent organic pollutants exposure during pregnancy, maternal gestational weight gain, and birth outcomes in themother-child cohort in Crete, Greece (RHEA study). Environ Int 2014, 64:116-123.

127. Su PH, Huang PC, Lin CY, Ying TH, Chen JY, Wang SL: The effect of in utero exposure to dioxins and polychlorinated biphenyls on reproductive development in eight year-old children. Environ Int 2012, 39:181-187.

128. lavicoli I, Fontana $L$, Leso $V$, Bergamaschi A: The effects of nanomaterials as endocrine disruptors. Int J Mol Sci 2013, 14:16732-16801.

129. Bordel R, Lasche MW, Menger MD, Vollmar B: Nicotine does not affect vascularization but inhibits growth of freely transplanted ovarian follicles by inducing granulosa cell apoptosis. Hum Reprod 2006, 21:610-617.

130. Zenzes MT, Krishnan S, Krishnan B, Zhang H, Casper RF: Cadmium accumulation in follicular fluid of women in in vitro fertilization-embryo transfer is higher in smokers. Fertil Steril 1995, 64:599-603.

131. Neal MS, Zhu J, Foster WG: Quantification of benzo[a]pyrene and other $\mathrm{PAHs}$ in the serum and follicular fluid of smokers versus non-smokers. Reprod Toxicol 2008, 25:100-106.

132. Fuentes A, Muñoz A, Pommer R, Argüello B, Galleguillos A, Torres A, Jesam C: Decreased anti-Müllerian hormone concentration in follicular fluid of female smokers undergoing artificial reproductive techniques. Chemosphere 2012, 88:403-406.

133. Fowler PA, Childs AJ, Courant F, Mackenzie A, Rhind S, Antignac JP, Filis P, Evans F, Flannigan S, Maheshwari A, Bhattacharya S, Monteiro A, Anderson RA, O'Shaughnessy PJ: In-utero exposure to cigarette smoke dysregulates 
human fetal ovarian developmental signaling. Hum Reprod 2014, 29:1471-1489.

134. Zenzes MT, Reed TE, Wang P, Klein J: Cotinine, a major metabolite of nicotine, is detectable in follicular fluids of passive smokers in in vitro fertilization therapy. Fertil Steril 1996, 66:614-619.

135. Benedict MD, Missmer SA, Vitonis AF, Cramer DW, Meeker JD: Cotinine concentrations in follicular fluid as a measure of secondhand tobacco smoke exposure in women undergoing in vitro fertilization: inter-matrix comparisons with urine and temporal variability. Chemosphere 2011, 84:110-116.

136. Santos RR, Schoevers EJ, Roelen BAJ, Fink-Gremmels J: Mycotoxins and female reproduction: in vitro approaches. World Mycotoxin J 2013, 6:245-253.

137. Petska JJ: Deoxynivalenol: mechanisms of action, human exposure, and toxicological relevance. Arch Toxicol 2010, 84:663-679.

138. Cortinovis C, Pizzo F, Spicer LI, Caloni F: Fusarium mycotoxins: effects on reproductive function in domestic animals - review. Theriogenology 2013, 80:557-564

139. Tiemann U, Tomek W, Schneider F, Müller M, Pöhland R, Vanselow J: The mycotoxins alternariol and alternariol methyl ether negatively affect progesterone synthesis in porcine granulosa cells in vitro. Toxicol Lett 2009, 186:139-145.

140. Wätjen W, Debbab A, Hohlfeld A, Chovolou Y, Proksch P: The mycotoxin beauvericin induces apoptotic cell death in H4IIE hepatoma cells accompanied by an inhibition of NF-kB-activity and modulation of MAP-kinases. Toxicol Lett 2014, 231:9-16.

141. Machtinger R, Combelles CM, Missmer SA, Correia KF, Williams P, Hauser R, Racowsky C: Bisphenol-A and human oocyte maturation in vitro. Hum Reprod 2013, 28:2735-2745.

142. Peretz J, Vrooman L, Ricke WA, Hunt PA, Ehrlich S, Hauser R, Padmanabhan V, Taylor HS, Swan SH, VandeVoort CA, Flaws JA: Bisphenol A and reproductive health: update of experimental and human evidence, 2007-2013. Environ Health Perspect 2014, 122:775-786.

143. Dinkins CL, Peterson RK: A human dietary risk assessment associated with glycoalkaloid responses of potato to Colorado potato beetle defoliation. Food Chem Toxicol 2008, 46:2837-2840.

144. Taciak M, Tusno A, Pastuszewska B: The effects of feeding diets containing potato protein concentrate on reproductive performance of rats and quality of the offspring. J Anim Physiol Anim Nutr 2011, 95:556-563.

145. Friedman M, Henika PR, Mackey BE: Effect of feeding soladine, solasodine and tomatidine to non-pregnant and pregnant mice. Food Chem Toxicol 2003, 41:61-71.

146. Yoshida N, Mizuno K: Effect of physiological levels of phytoestrogens on mouse oocyte maturation in vitro. Cytotechnology 2012, 64:241-247.

147. Kaludjerovic J, Chen J, Ward WE: Early life exposure to genistein and daidzein disrupts structural development of reproductive organs in female mice. J Toxicol Environ Health A 2012, 75:649-660.

148. Jefferson WN, Patisaul HB, Williams CJ: Reproductive consequences of developmental phytoestrogen exposure. Reproduction 2012, 143:247-260

149. Chan-Hon-Tong A, Charles MA, Forhan A, Heude B, Sirot V: Exposure to food contaminants during pregnancy. Sci Total Environ 2013, 458-460:27-35.

150. Kjaerstad MB, Taxvig C, Nellemann C, Vinggaard AM, Andersen HR: Endocrine disrupting effects in vitro of conazole antifungals used as pesticides and pharmaceuticals. Reprod Toxicol 2010, 30:573-582.

151. Longo M, Zanoncelli S, Colombo PA, Harhay MO, Scandale I, Mackenzie C, Geary T, Madrill N, Mazué G: Effects of the benzimidazole anthelmintic drug flubendazole on rat embryos in vitro. Reprod Toxicol 2013, 36:78-87.

152. Clarck RL: Embryotoxicity of the artemisinin antimalarials and potential consequences for use in women in the first trimester. Reprod Toxicol 2009, 28:285-296.

153. Hatch EE, Troisi R, Wise LA, Titus-Ersntoff L, Hyer M, Palmer JR, Strohsnitter WC, Robboy SJ, Anderson D, Kaufman R, Adam E, Hoover RN: Preterm birth, fetal growth, and age at menarche among women exposed prenatally to diethylstilbestrol (DES). Reprod Toxicol 2011, 31:151-157.

154. Cassina M, Dilaghi A, Di Gianantonio E, Cesari E, De Santis M, Mannaioni G, Pistelli A, Clementi M: Pregnancy outcome in women exposed to antiepileptic drugs: teratogenic role of maternal epilepsy and its pharmacologic treatment. Reprod Toxicol 2013, 39:50-57.

155. Roness H, Kalich-Philosoph L, Meirow D: Prevention of chemotherapy-induced ovarian damage: possible roles for hormonal and non-hormonal attenuating agents. Hum Reprod Update 2014, 20:759-774.
156. Vela-Soria F, Ballesteros O, Zafra-Gómez A, Ballesteros L, Navalón A: A new method for the determination of benzophenone-UV filters in human serum samples by dispersive liquid-liquid microextraction with liquid chromatography-tandem spectrometry. Talanta 2014, 121:97-104.

157. Nau H: Embryotoxicity and teratogenicity of topical retinoic acid. Skin Pharmacol 1993, 1:35-44.

158. Tahaei LS, Eimani H, Yazdi PE, Ebrahimi B, Fathi R: Effects of retinoic acid on maturation of immature mouse oocyte in the presence and absence of a granulosa cell co-culture system. J Assist Reprod Genet 2011, 28:553-558.

159. Sitarek K, Gromadzinska J, Lutz P, Stetkiewicz J, Swiercz R, Wasowicz W: Fertility and developmental toxicity studies of diethylene glycol monobutyl ether (DGBE) in rats. Int I Occup Med Environ Health 2012, 25:404-417.

160. Roberts JR, Karr CJ: Council on environmental health: pesticide exposure in children. Pediatrics 2012, 130:1765-1788.

161. Snijder CA, te Velde E, Roeleveld N, Burdorf A: Occupational exposure to chemical substances and time to pregnancy: a systematic review. Hum Reprod Update 2012, 18:284-300.

doi:10.1186/1477-7827-12-117

Cite this article as: Santos et al: Usefulness of bovine and porcine IVM/IVF models for reproductive toxicology. Reproductive Biology and Endocrinology 2014 12:117.

\section{Submit your next manuscript to BioMed Central and take full advantage of:}

- Convenient online submission

- Thorough peer review

- No space constraints or color figure charges

- Immediate publication on acceptance

- Inclusion in PubMed, CAS, Scopus and Google Scholar

- Research which is freely available for redistribution 